\title{
EFEKTIFITAS MINUMAN KUNYIT ASAM DALAM PENURUNAN SKALA NYERI HAID
}

\author{
Maya Safitri \\ Prodi Kebidanan DIII STIKES Harapan Bangsa Purwokerto \\ Email :ma.ya08@yahoo.com
}

\begin{abstract}
Saur turmeric drink is a beverage that is processed with the main ingredient of turmeric. Naturally, turmeric is believed to contain active ingredients that can serve as analgesic, antipyretic and anti-inflammatory. In addition it is explained that turmeric drink as a reducer of pain in primary dysmenorhoea has minimal side effects (Limananti \& Triratnawati, 2003). The active compounds or chemicals contained in turmeric are Curcumine (Putri, 2006). Based on preliminary study obtained from the results of interviews on 20 female students of STIKES Harapan Bangsa Purwokerto midwifery study program, there are still many students who do not know the benefits of turmeric as a pain reliever during menstruation.

The purpose of this study is to determine the effect of turmeric on the decrease of primary menstrual pain level in female students midwifery STIKES Harapan Bangsa Purwokerto.

The research model used was quasi experiment and technique of research sample using Purposive sampling. The results of this research are scientific publications, leaflets and textbooks.

The conclusion by using paired $T$ test is by comparing menstrual pain experienced by respondents before the intervention and after the intervention showed no effect of turmeric acid on the decrease of primary menstrual pain indicated by the value of $P$ value $=0.0001$ which means $<\alpha 0.05$.
\end{abstract}

Keywords: Dismenorhea, sour turmeric drink, decreased pain

\section{PENDAHULUAN}

Haid (menstruasi) merupakan proses pengeluaran darah dari uterus disertai serpihan selaput dinding uterus pada wanita dewasa yang terjadi secara periodik (Maulana, 2009). Pada saat dan sebelum haid (menstruasi), seringkali wanita mengalami rasa tidak nyaman di perut bagian bawah. Akan tetapi jika rasa tidak nyaman itu sampai mengganggu sehingga harus meninggalkan pekerjaannya dan memaksanya harus beristirahat atau mencari pengobatan keadaan ini disebut sebagai nyeri haid (dismenorea). Ada dua jenis dismenorea, yaitu primer dan sekunder. Pada masa puber ini biasanya dismenorea yang dialami adalah dismenorea primer (Manuaba, 2009)

Untuk mengatasi nyeri haid (dismenorea) dapat dilakukan dengan terapi farmakologi dan non farmakologi. Terapi farmakologi antara lain, pemberian obat analgetik, terapi hormonal, obat nonsteroid prostaglandin, dan dilatasi kanalis servikalis (Saifuddin, et al. 2008). Untuk terapi nonfarmakologi dilakukan dengan antara lain kompres hangat, olahraga, terapi mozart, dan relaksasi, dan minum minuman herbal (Saifudin, 2008).

Produk herbal saat ini memang sedang menjadi alternatif terutama bagi remaja putri yang ingin mengurangi rasa nyeri tanpa 
mendapatkan efek samping (Triratnawati, 2003). Salah satu produk herbal yang familiar untuk mengurangi nyeri haid adalah minuman kunyit. Dalam hal ini masyarakat Indonesia percaya bahwa memiliki kebiasaan minum minuman kunyit untuk mengurangi keluhan pada saat haid. Namun, masyarakat belum mengetahui kandungan dari kunyit itu sendiri.

Minuman kunyit adalah suatu minuman yang diolah dengan bahan utama kunyit. Secara alamiah memang kunyit dipercaya memiliki kandungan bahan aktif yang dapat berfungsi sebagai analgetika,antipiretika,dan antiinflamasi. Selain itu dijelaskan bahwa minuman kunyit sebagai pengurang rasa nyeri pada dismenore primer memiliki efek Samping minimal (Limananti\&Triratnawati, 2003). Senyawa aktif atau bahan kimia yang terkandung dalam kunyit adalah Curcumin (Putri, 2006).

Curcumine akan bekerja dalam menghambat rekasi cyclooxygenase(COX-2) sehingga menghambat atau mengurangi terjadinya inflamasi sehingga akan mengurangi atau bahkan menghambat kontraksi uterus.Dan curcumenol sebagai analgetik akan menghambat Pelepasan prostaglandin yang berlebihan melalui jaringan epitel uterus dan akan menghambat kontraksi uterus sehingga akan mengurangi terjadinya dismenore(Wiesere, 2007).

Berdasarkan studi pendahuluan yang diperoleh dari hasil wawancara pada 20 mahasiswi program studi kebidanan STIKES Harapan Bangsa Purwokerto menunjukkan bahwa $45 \%$ mengatakan nyeri ringan, $40 \%$ nyeri sedang, $15 \%$ nyeri berat dan masih banyak mahasiswa yang belum mengetahui manfaat minuman kunyit sebagai pereda rasa nyeri saat menstruasi. Responden melakukan penanganan dismenorea dengan menggunakan minyak kayu putih, istirahat di tempat tidur, dan ada yang tidak melakukan apa-apa.

Dari permasalahan diatas maka peneliti tertarik untuk melakukan penelitian tentang "pengaruh minuman kunyit asam terhadap penurunan nyeri haid primer".

\section{METODE}

Model penelitian yang digunakan adalah quasi eksperimen. Rancangan penelitian ini adalah pre-posttest one group design yaitu suatu rancangan sebelum dan sesudah dilakukan intervensi. Populasi dalam penelitian ini adalah semua Mahasiswi Stikes Harapan Bangsa Program Studi Kebidanan D3. Tingkat nyeri akan diukur menggunakan Numeric Rating Scale (1-10). Sampel dengan menggunakan Purposive sampling dengan jumlah sampel 20 mahasiswi dengan cara memberikan minuman kunyit asam saat nyeri haid 1 gelas belimbing sekitar $200 \mathrm{ml}$ biasanya pada hari kedua menstruasi sebelummya di ukur skala nyeri kemudian minum kunyit asam selang 1 jam di ukur skala nyeri sesudah minum kunyit asam. Skala nyeri sebelum intervensi dan sesudah intervensi akan di dianalisa univariat. Analisa bivariate uji statistic menggunkan uji t tidak berpasangan dengan tingkat kemaknaan $p=$ 0,05 . 
HASIL

Setelah dilakukan penelitian dengan mengadakan wawancara dan pengisian data ke dalam kuesioner kepada para mahasiswa prodi kebidanan sejumlah 20 orang yang memiliki rentang usia 18 sampai dengan 21 tahun mengenai perbedaan skala nyeri sebelum dan sesudah minum kunyit asam pada dismenorhea primer, diperoleh data sebagai berikut:

Dari 20 mahasiswi yang mengalami dismenorhea primer mendapatkan intervensi yaitu minum minuman kunyit asam saat dismenorhea berlangsung. Setelah dilakukan intervensi tersebut, mahasiswi sudah tidak memiliki keluhan lagi saat menstruasi.

Dari 20 yang mengalami dismenorhea primer tetapi tidak mendapatkan intervensi yaitu minum minuman kunyit asam saat dismenorhea berlangsung sebagian besar ada yang masih merasakan nyeri haid dan sebagian ada yang mengalami penurunan nyeri haid. Berikut ini adalah tabel hasil penelitian yang telah dilakukan

Tabel 1. Karakteristik Reponden Berdasarkan Usia

\begin{tabular}{lccccc}
\hline & \multicolumn{5}{c}{ Umur (tahun) } \\
\cline { 2 - 6 } kelompok & $\mathrm{N}$ & Mean & $\begin{array}{c}\text { Std } \\
\text { Deviasi }\end{array}$ & Min & Maks \\
& \multicolumn{5}{c}{ Deviar } \\
\hline umur & 20 & 19,70 & 0,801 & 18 & 21 \\
\hline
\end{tabular}

Berdasarkan Tabel 1 diketahui bahwa ratarata usia responden adalah 19 tahun 7 bulan, umur minimal adalah 18 tahun dan umur maksimal responden adalah 21 tahun.
Tabel 2. Nyeri haid sebelum intervensi

\begin{tabular}{lcc}
\hline \multicolumn{1}{c}{ Skala Nyeri } & F & $\%$ \\
\hline Tidak Nyeri & 0 & 0 \\
Nyeri ringan & 5 & 25 \\
Nyeri Sedang & 13 & 65 \\
Nyeri Berat & 2 & 10 \\
Nyeri tak tertahankan & & \\
& 0 & 0 \\
\hline & 20 & 100 \\
\hline
\end{tabular}

Berdasarkan Tabel 2 dapat diketahui bahwa nyeri haid sebelum intervensi pada kelompok kontrol sebagian besar berada pada kategori nyeri sedang yaitu sebanyak 13 responden $(65 \%)$.

Tabel 3.Nyeri haid setelah intervensi

\begin{tabular}{lcc}
\hline \multicolumn{1}{c}{ Skala Nyeri } & f & $\%$ \\
\hline Tidak Nyeri & 8 & 40 \\
Nyeri ringan & 5 & 25 \\
Nyeri Sedang & 6 & 30 \\
Nyeri Berat & 1 & 5 \\
Nyeri tak tertahankan & & \\
& 0 & 0 \\
\hline & 20 & 100 \\
\hline
\end{tabular}

Berdasarkan Tabel 3 dapat diketahui bahwa nyeri haid setelah intervensi sebagian besar responden berada pada kategori tidak nyeri yaitu sebanyak 8 responden (40\%). Hasil penelitian menunjukkan bahwa terjadi peningkatan penurunan nyeri haid dengan kriteria nyeri sedang menjadi tidak nyeri setelah responden mengkonsumsi minuman kunyit asam dan diukur kembali skala nyerinya setelah 1 jam pemberian intervensi. 
Tabel 4. Pengaruh Minuman Kunyit Asam Terhadap Penurunan Nyeri Haid

Skala Nyeri Mean Standar Deviasi P Value

\begin{tabular}{llll}
\hline Pre intervensi & 1,85 & 0,587 & 0,0001 \\
Post Intervensi & 1,00 & 0,973 &
\end{tabular}

Berdasarkan Tabel 4 dapat disimpulkan bahwa dari hasil perhitungan dengan menggunakan Uji T berpasangan yaitu dengan membandingkan nyeri haid yang dialami responden sebelum dilakukan intervensi dan setelah dilakukan intervensi menunjukkan ada pengaruh minuman kunyit asam terhadap penurunan nyeri haid primer yang ditunjukkan dengan nilai $\mathrm{P}$ value $=0,0001$ yang berati $<\alpha$ 0,05 . Hal ini menyebabkan Ha diterima dan Ho ditolak yaitu ada pengaruh minuman kunyit asam terhadap penurunan nyeri haid primer pada mahasiswi program studi kebidanan.

\section{PEMBAHASAN}

\section{Karakteristik usia responden}

Berdasarkan pada hasil penelitian yang telah didapatkan rata-rata usia responden adalah 19,7 tahun dengan usia minimum 18 tahun dan maximum 21 tahun. Hal ini sesuai dengan penelitian sebelumnya yaitu penelitian yang dilakukan oleh Novia dan Puspitasari (2008) tentang faktor-faktor yang mempengaruhi kejadian dismenore primer. Penelitian menunjukan bahwa dismenore primer lebih banyak ditemukan pada rentang usia 15-25 tahun dengan persentase $87 \%$ pada jumlah responden 100 orang. Penelitian lainnya oleh Ortiz (2010) menunjukan bahwa rata-rata usia responden yang mengalami dismenore adalah 17-35 tahun. Dismenore primer umumnya dimulai pada 1-3 tahun setelah haid pertama (menarche). Kasus ini bertambah berat beberapa tahun hingga usia 23-27 tahun (Morgan dan Hamilton, 2009).

\section{Skala nyeri dismenore pre dan post}

Sebagian besar responden mengalami penurunan skala nyeri pre yaitu nyeri sedang dengan prosentase $65 \%$, sedangkan pada pengukuran post sebagian responden mengalami penurunan nyeri haid menjadi tidak nyeri dengan presentase $40 \%$, selain itu juga ada peningkatan jumlah responden yang tidak mengalami nyeri haid menjadi $40 \%$ dari $0 \%$. Hasil penelitian tersebut didukung oleh Marlina (2012) tentang pengaruh minuman kunyit asam terhadap nyeri dismenore primer yang menunjukan bahwa ada penurunan skala nyeri berat menjadi sedang dan skala nyeri sedang menjadi ringan. Ramuan yang diberikan mampu mengurangi nyeri responden sehingga mereka dapat melanjutkan aktivitas sehari-hari.

\section{Pengaruh minuman kunyit asam asam} Terhadap Penurunan Nyeri Haid Primer

Berdasarkan hasil uji statistik Uji $T$ berpasangan didapatkan hasil bahwa nilai $\mathrm{P}$ value adalah 0,0001 yang berati $<\alpha 0,05$ yang menyimpulkan bahwa Ha diterima dan Ho ditolak. Hal ini menunjukkan bahwa ada pengaruh minuman kunyit asam terhadap penurunan nyeri haid primer pada mahasiswi program studi kebidanan. Minuman kunyit adalah suatu minuman yang diolah dengan bahan utama kunyit. Secara alamiah memang kunyit dipercaya memiliki kandungan bahan aktif yang dapat berfungsi sebagai analgetika,antipiretika,dan antiinflamasi. 
Selain itu dijelaskan bahwa minuman kunyit sebagai pengurang rasa nyeri pada dismenore primer memiliki efek Samping minimal (Limananti\&Triratnawati, 2003). Senyawa aktif atau bahan kimia yang terkandung dalam kunyit adalah Curcumin (Putri, 2006).

Curcumine akan bekerja dalam menghambat rekasi cyclooxygenase (COX-2) sehingga menghambat atau mengurangi terjadinya inflamasi sehingga akan mengurangi atau bahkan menghambat kontraksi uterus.Dan curcumenol sebagai analgetik akan menghambat Pelepasan prostaglandin yang berlebihan melalui jaringan epitel uterus dan akan menghambat kontraksi uterus sehingga akan mengurangi terjadinya dismenore (Wiesere, 2007).

Saat ini patofisiologi terjadinya dismenorea primer memang masih belum jelas karena banyaknya faktor yang mempengaruhi terjadinya dismenorea primer pada remaja putri. Teori Dismeorhea primer yang dipercaya kebenarannya yaitu teori prostaglandin dan leukotrien (Harel, 2006). Penurunan hormon progesteron dan estrogen pascaovulasi nonfertilisasi menyebabkan menstruasi yang mengakibatkan aktivasi siklus prostaglandin dan leukotrien dalam uterus (Guyton dan Hall, 2007). Respons inflamasi akibat siklus prostaglandin di dalam uterus akan berakibat pada hipertonus dan vasokonstriksi pada miometrium. Akhirnya timbul iskemia dan nyeri pada dismenorea primer (Hillard, 2006). Substansi spesifik yang menyebabkan hal ini adalah prostaglandin (PG) F2-alfa. Prostaglandin F2 alfa adalah salah satu perangsang kuat kontraksi otot polos myometrium dan kontriksi pembuluh darah uterus.

Leukotrien lebih berperan dalam hal peningkatan sensitivitas serabut saraf nyeri uterus (Hillard, 2006). Dismenorea primer juga bisa disebabkan oleh tekanan psikis atau stres. Tekanan psikis yang dialami seseorang akan meningkatkan katekolamin. Hal ini berakibat pada vasokonstriksi dan iskemia selsel uterus. Kemudian akan terjadi proses inflamasi yang merupakan faktor pemicu terjadinya dismenorea primer (Harel, 2006).

Pada penelitian ini responden diberikan intervensi minuman kunyit pada saat mereka mengalami dismenorhea primer. Saat responden sudah dilakukan intervensi kemudian diukur kembali nyeri haidnya 1 jam setelah mereka mengkonsumsi minuman kunyit. Hasil dari intervensi ini adalah sebagian besar responden mengalami penurunan nyeri haid. Hasil penelitian sesuai dengan teori yang diungkapkan oleh Hatcher (2008) yang mengatakan bahwa minuman kunyit asam memiliki khasiat dasar sebagai analgetika dan antiinflamasi. Agen aktif dalam kunyit yang berfungsi sebagai antiinflamasi dan antipiretika adalah curcumine, sedangkan sebagai analgetika adalah curcumenol. Kasiat tambahan buah asam jawa pada minuman kunyit asam memiliki agen aktif alami anthocyanin sebagai antiinflamasi dan antipiretika. Buah asam jawa juga memiliki kandungan tannins, saponins, sesquiterpenes, alkaloid, dan phlobotamins untuk mengurangi aktivitas sistem saraf. Telah dijelaskan sebelumnya bahwa kunyit memiliki efektivitas yang sama dengan ibuprofen dalam 
mengurangi nyeri. Secara umum ibuprofen dikenal sangat cepat dan efektif diserap setelah pemberian peroral. Puncak konsentrasi di dalam plasma sangat singkat yaitu antara 15 menit-1 jam. Kerja dari ibuprofen pun sama dengan kunyit yaitu dengan menghambat sintesis prostaglandin. Obat-obat/herbal yang sejenis dengan ibuprofen sangat mudah diabsorbsi oleh sistem gastrointestinal. Waktu paruh obat adalah waktu yang diperlukan obat untuk dimetabolisme. Waktu paruh ibuprofen relatif singkat (Kee \& Hayes, 1996). Hasil penelitian ini didukung oleh Penelitian Marlina (2012) menunjukan bahwa dari 17 siswi SMA yang mengalami nyeri dismenore berat mengalami penurunan nyeri menjadi nyeri sedang, 11 siswi yang mengalami nyeri sedang mengalami penurunan menjadi nyeri dengan intensitas ringan. Penurunan nyeri ini dialami 15 menit setelah para siswi meminum minuman kunyit asam. Curcumin yang terkandung dalam kunyit mampu menghambat sintesis prostaglandin sama halnya seperti gingerol dalam jahe (Marlina, 2012).

Lebih spesifik dapat dijelaskan bahwa kandungan curcumine pada kunyit dan anthocyanin pada asam jawa akan menghambat proses inflamasi yang berperan sebagai inhibitor enzim siklooksigenase (COX) (Almada, 2000; Hoppe, 2010; Wieser, et al., 2007). Mekanisme biokimia terpenting yang dihambat oleh curcumine adalah influks ion kalsium ke dalam sel-sel epitel uterus. Jika penghambatan terhadap influks ion ini dilakukan ke dalam sel epitel uterus, maka kontraksi uterus bisa dikurangi atau bahkan dihilangkan sehingga tidak terjadi dismenorea primer (Thaina, et al., 2009). . Hal ini sesuai dengan tinjauan teori yang telah diungkapkan sebelumnya mengenai bahan-bahan aktif yang terdapat dalam kunyit dan asam. Baik kunyit asam sebagai antiinflamasi, analgetika dan antipiretika, maupun sebagai penenang yang bisa menghindarkan stimulasi saraf simpatis dari stres yang sering dialami remaja putri oleh karena aktivitasnya sehari-hari.

Jadi secara garis besar, sesuai dengan pendapat-pendapat peneliti yang telah disebutkan sebelumya, mengenai buah rimpang kunyit dan buah asam yang kemudian diolah menjadi minuman kunyit asam, bahwa gabungan kedua komponen tersebut mengandung berbagai bahan aktif alami yang dapat menurunkan aktivitas enzim siklooksigenase (COX) sehingga dapat menurunkan reaksi inflamasi, mengurangi pelepasan prostaglandin saat menstruasi, menekan aktivitas sistem saraf otonom sehingga menekan terjadinya kontraksi dan vasospasme uterus yang berlebihan, dan mengurangi stres emosional yang bekerja melalui sistem saraf otonom.

\section{SIMPULAN DAN SARAN}

\section{a. Simpulan}

Pada penelitian ini dapat disimpulkan bahwa terdapat pengaruh minuman kunyit asam terhadap penurunan nyeri haid, sebelum intervensi nyeri haid skala sedang terjadi pada 13 mahasiswa (65\%) setelah intervensi nyeri haid skala sedang menurun menjadi 6 mahasiswa (35\%) sisanya 8 mahasiswa (40\%) 
tidak nyeri.

\section{b. Saran}

Penelitian ini bisa dijadikan referensi bidang farmakologi atau obat alternatif untuk mengurangi nyeri haid, dan bagi peneliti selanjutnya bisa meneliti faktor-faktor yang mempengaruhi nyeri saat pemberian terapi dengan jumlah responden dan lingkup yang lebih luas.

\section{DAFTAR PUSTAKA}

Andrews, Gilly. 2009. Buku Ajar Kesehatan Reproduksi Wanita, Edisi 2. Jakarta: EGC.

Handayani, 2012. Dismenore dan Kecemasan Pada Remaja. Available from: etd.ugm.ac.id/index.php?mod=downloa d\&sub. [Accessed 8/04/13].

Hidayat, A. Aziz Alimul. 2006. Pengantar Kebutuhan Dasar Manusia. Jakarta: Salemba Medika.

Kozier, Erb, Berman, Snyder 2011. Buku Ajar Fundamental Keperawatan: Konsep, Proses dan Praktik. Jakarta: EGC.

Perry \& Potter. 2009. Fundamental Keperawatan .Edisi 7. Jakarta: Salemba Medika.

Puji A, Istiqomah. 2009. Efektivitas Senam Dismenore dalam Mengurangi Dismenore pada Remaja Putri di SMUN 5 Semarang. Available from:

Sabhinaya, Kartika. 2011. Hubungan antara status gizi dan usia menarche terhadap dismenore primer pada siswi kelas IX SMPN 87 Jakarta Tahun 2011. A va i 1 a ble from : http://library.upnvj.ac.id/index.php? $\mathrm{p}=\mathrm{s}$ how_detail\&id=8238 [Accessed 06/01/13].

Setyawanti. 2010. Relaksasi Otot Progresif dapat Menurunkan Nyeri Menstruasi pada Siswi SMP UNESA 2 Surabaya. A v a i 1 a b 1 e fro m : http://alumni.unair.ac.id/kumpulanfile/1 0040838082_abs.pdf. [Accessed 06/01/13].

Riniasih, Wahyu. 2008. Efektivitas Aromaterapi Rose dalam Mengatasi Dismenore pada Remaja Putri di Pondok Pesantren Darut Taqwa Bulusan Tembalang Semarang. A $\quad \mathrm{v}$ a $\mathrm{i} \quad 1$ a b 1 e from:http://www.google.com/url?sa= $\mathrm{t} \& \mathrm{rct}=\mathrm{j} \& \mathrm{q}=$ aromaterapi + dan + dismenor e. + pdf $\&$ source $=$ web $\& \mathrm{~cd}=3 \&$ ved $=0 \mathrm{CD}$ oQFjAC\&url=http $\% 3 \mathrm{~A} \% 2 \mathrm{~F} \% 2 \mathrm{Feprint}$ s.undip.ac.id $\% 2$ F $10346 \%$

Reeder, Sharon. J, Martin, Leonide L, dan Griffin, Deborah Koniak. 2011. Keperawatan Maternitas: Kesehatan Wanita, Bayi dan Keluarga, Edisi 8. Jakarta: EGC.

Notoatmodjo, S. 2010. Metodologi Penelitian Kesehatan. Jakarta: Rineka Cipta.

Morgan \& Hamilton. 2009. Obstetri dan Ginekologi: Panduan Praktik, Edisi 2. Jakarta: EGC.

Nuryanah. 2010. Perbandingan efektivitas kompres air hangat dan aromaterapi jasmine terhadap penurunan tingkat nyeri menstruasi pada siswi SMP GIKI 2 $S u r a b a y a$. A v a i 1 a b $1 \mathrm{e}$ from:http://alumni.unair.ac.id/detail.ph $\mathrm{p} ? \mathrm{id}=326$ 